\title{
INTERACTIONS BETWEEN BIFIDOBACTERIUM BIFIDUM N4 AND ESCHERICHIA COLI K-12 IN THEIR MIXED CULTURES ${ }^{1}$
}

\author{
Eiichi Hara, ${ }^{2}$ Kouhei Yazawa, Hiroshi NaKamura, \\ and Zenzo TAMURA ${ }^{3}$ \\ Faculty of Pharmaceutical Sciences, University of Tokyo, \\ Hongo, Bunkyo-ku, Tokyo 113, Japan
}

(Received August 21, 1978)

\begin{abstract}
Summary The interactions between Bifidobacterium bifidum N4 (B. bifidum) and Escherichia coli K-12 (E. coli) were investigated in their mixed cultures.

Under conditions in which both bacteria grew well in their pure culture, $B$. bifidum inhibited the growth of $E$. coli even when the latter was inoculated at $10^{4}$-fold and preincubated for $41 \mathrm{hr}$. The inhibition in the mixed cultures appeared when the $\mathrm{pH}$ values were reduced below 4.6. When the lowering of $\mathrm{pH}$ was prevented by the addition of $\mathrm{NaOH}$, no inhibition was observed. At the same initial $\mathrm{pH}$ of 6.5 , lactic acid and acetic acid, metabolites of $B$. bifidum, had more inhibitory effect on the growth of $E$. coli than other aliphatic fatty acids.

On the other hand, in the mixed cultures with E. coli, B. bifidum grew in the absence of its essential vitamins, riboflavin and pantetheine and, furthermore, aerobically.
\end{abstract}

Bifidobacteria are predominantly living bacteria in the digestive duct (1) and believed to be associated with human health, especially that of infants (2). There have been many attempts to increase the number of Bifidobacteria in the intestine (3). Their proliferation in the duct is closely related to their interactions with other intestinal microorganisms, which should be elucidated.

Interactions of Lactobacillus acidophilus (L. acidophilus), which has properties similar to Bifidobacterium bifidum (B. bifidum), with different kinds of bacteria have

\footnotetext{
1 A part of this work was presented at the 95th Annual Meeting of Pharmaceutical Society of Japan, Osaka, April, 1975.

2 Present address: Biochemistry Division, Saitama Cancer Center Research Institute, Ina-machi, Saitama 362, to whom correspondence should be addressed.

3 原 栄一, 矢沢幸平, 中村 洋, 田村善藏
} 
been reported. TORREY and KAHN (4) reported that Bacterium acidophilus (now called $L$. acidophilus) inhibited the proteolytic anaerobes and this inhibition was due to the lowering of $\mathrm{pH}$ values caused by the former metabolites, lactic acid and acetic acid. Young et al.(5) also mentioned that in the interaction between Candida albicans and $L$. acidophilus there were parasitic and antagonistic phenomena.

In this paper we made media for the selective counting of the number of viable cells grown in the culture by a capillary tube method, originally developed by YANAGITA (6), and then the parasitic and antagonistic phenomena between $B$. bifidum $\mathrm{N} 4$ and Escherichia coli K-12 (E. coli) in their mixed cultures were investigated from nutritional and physiological points of view.

\section{MATERIALS AND METHODS}

Chemicals. Polypeptone (Daigo Nutrition Chemicals Co.), bacto-agar, casamino acids and yeast extract (Difco Laboratories), and sodium azide (E. Merck) were used. Other chemicals were of analytical grade. A set of $\mathrm{pH}$ indicator papers (Toyo Roshi Co.) were used for $\mathrm{pH}$ measurement.

Bacteria. B. bifidum $\mathrm{N} 4$ and $E$. coli $\mathrm{K}-12$ were used throughout this experiment.

Determination of the growth of both bacteria. The viable cells of B. bifidum and $E$. coli in a sample were determined by the capillary tube method using the selective media. The selective media for both bacteria are shown in "Results." The procedures were performed according to NAKAMURA et al.(7). The turbidities of cultures were measured by a Photo-Electric Spectrophotometer Type 6B (Hirama Rika Kenkyujo, Kawasaki) at $650 \mathrm{~nm}$.

Preincubation. Both bacteria were preincubated in a preculture medium $(8)$ for B. bifidum (arbitrarily called Medium D), which consists of $3.2 \mathrm{~g}$ polypeptone, $8.0 \mathrm{~g}$ casamino acids, $0.4 \mathrm{~g}$ L-cysteine, $4.8 \mathrm{~g}$ yeast extract, $10 \mathrm{~g}$ lactose, $3.2 \mathrm{~g} \mathrm{NaCl}$ in $1,000 \mathrm{ml}$ of distilled water adjusted to $\mathrm{pH} 6.8$. B. bifidum was incubated at $37^{\circ} \mathrm{C}$ under an atmosphere of $10 \% \mathrm{CO}_{2}: 90 \% \mathrm{~N}_{2}$ (anaerobic incubation) and $E$. coli aerobically at $37^{\circ} \mathrm{C}$ for $24 \mathrm{hr}$.

Preparation of inoculum. Both bacteria were separately preincubated, washed three times with $5 \mathrm{ml}$ of sterile physiological saline and suspended in $5 \mathrm{ml}$ of the saline. After proper repetitions of ten-fold dilutions with the saline, a $0.1 \mathrm{ml}$ aliquot was inoculated into the media described below to make the final volume $7 \mathrm{ml}$.

Medium for testing the interactions between B. bifidum and E. coli. For this purpose two standard media were used. One was Medium $D$ and another a complete synthetic medium, modified György medium used by NAKAMURA et al. (9) (arbitrarily called GM-medium). The composition of GM-medium is as follows: $2.5 \mathrm{~g} \mathrm{~K}_{2} \mathrm{HPO}_{4} ; 35 \mathrm{~g}$ lactose; $25 \mathrm{~g} \mathrm{CH}_{3} \mathrm{COONa} ; 5.0 \mathrm{~g}$ vitamin-free casamino acids; $0.2 \mathrm{~g}$ alanine, $\mathrm{L}$-cysteine and tryptophan; $0.1 \mathrm{~g}$ asparagine; $0.01 \mathrm{~g}$ xanthine, adenine, guanine and uracil; $0.2 \mathrm{mg}$ thiamine $\cdot \mathrm{HCl}$ and riboflavin; $1.2 \mathrm{mg}$ pyridoxine; $0.6 \mathrm{mg}$ 
nicotinic acid; $12.5 \mu \mathrm{g}$ PABA ( $p$-aminobenzoic acid), folic acid and biotin; $50 \mu \mathrm{g}$ pantetheine; $200 \mathrm{mg} \mathrm{MgSO}_{4} \cdot 7 \mathrm{H}_{2} \mathrm{O} ; 10 \mathrm{mg} \mathrm{NaCl} ; 6 \mathrm{mg} \mathrm{MnSO}_{4}$ in $1,000 \mathrm{ml}$ of distilled water at $\mathrm{pH} 6.8$.

\section{RESULTS}

Selective media for counting the number of viable cells of B. bifidum and E. coli

Medium D, a preculture medium for B. bifidum, was added with $0.002 \%$ BCG (bromcresol green) and $0.15 \%$ agar, and modified as below to produce the media for the capillary tube method.

From the data in Table $1,0.02 \% \mathrm{NaN}_{3}$ was added to the medium for counting the number of viable cells of $B$. bifidum. Coexistence of $E$. coli had no influence on the production of the colonies as in Table 2.

Table 1. Effect of sodium azide on the number of colonies of $B$. bifidum and $E$. coli.

\begin{tabular}{ccc}
\hline $\mathrm{NaN}_{3}(\%)$ & $\begin{array}{c}\text { B. bifidum }\left(10^{5} \text { diln. }\right) \\
\text { Mean } \pm \mathrm{SD}\end{array}$ & $\begin{array}{c}\text { E. coli }\left(10^{\circ} \text { diln. }\right) \\
\text { Mean }\end{array}$ \\
\hline 0 & $183 \pm 8.7$ & $++^{*}$ \\
0.004 & $193 \pm 9.5$ & $+^{*}$ \\
0.008 & $212 \pm 6.6$ & 0 \\
0.012 & $189 \pm 8.0$ & 0 \\
0.016 & $195 \pm 17.0$ & 0 \\
0.020 & $202 \pm 11.0$ & 0 \\
\hline
\end{tabular}

The experiments were carried out in triplicate. The data are given as the number of colonies produced in $0.5 \mathrm{ml}$ of the counting medium, $\left(++^{*}\right.$ or $\left.+^{*}\right)$ represents that the growth of $E$. coli was detectable, but the number of colonies was not determined due to the occurrence of cracks.

Table 2. Number of colonies produced by B. bifidum in the presence of $E$. coli using the selective medium for $B$. bifidum.

\begin{tabular}{|c|c|c|}
\hline \multicolumn{2}{|c|}{ Test strain } & \multirow{2}{*}{$\begin{array}{c}\text { Number of colonies } \\
\text { Mean } \pm \text { SD }\end{array}$} \\
\hline $\begin{array}{l}\text { B. bifidum } \\
\text { (diln.) }\end{array}$ & $\begin{array}{l}\text { E. coli } \\
\text { (diln.) }\end{array}$ & \\
\hline $10^{5}$ & $10^{\circ}$ & $130 \pm 6.7$ \\
\hline $10^{5}$ & $10^{1}$ & $152 \pm 2.7$ \\
\hline $10^{5}$ & $10^{2}$ & $155 \pm 15.9$ \\
\hline $10^{5}$ & $10^{3}$ & $159 \pm 16.8$ \\
\hline $10^{5}$ & $10^{4}$ & $152 \pm 3.2$ \\
\hline $10^{5}$ & $10^{5}$ & $155 \pm 18.0$ \\
\hline $10^{5}$ & $10^{6}$ & $140 \pm 13.3$ \\
\hline $10^{5}$ & $*$ & $160 \pm 3.5$ \\
\hline
\end{tabular}

Both $0.1 \mathrm{ml}$ of $10^{5}$-fold diluted culture of $B$. bifidum and appropriately diluted culture of $E$. coli were added to selective medium for $B$. bifidum. The experiments were carried out in triplicate. The data were shown as in Table 1 . The symbol $\left({ }^{*}\right)$ represents that saline was replaced with diluted culture of E. coli. 
As reported by NAKAMURA et al. (10), no colonies of $B$. bifidum were detected by removing lactose from the medium. From the data in Table $3,1.5 \% \mathrm{KNO}_{3}(6)$ was added to the medium to prevent the appearance of any cracks produced by $E$. coli. Coexistence of $B$. bifidum did not affect the production of the colonies as in Table 4.

Table 3. Effect of potassium nitrate on the suppression of cracks produced by $E$. coli.

\begin{tabular}{|c|c|c|}
\hline \multirow{2}{*}{$\mathrm{KNO}_{3}(\%)$} & \multicolumn{2}{|c|}{ E. coli $\left(10^{5}\right.$ diln. $)$} \\
\hline & Mean $\pm S D$ & $\begin{array}{l}\text { Occurrence } \\
\text { of cracks }\end{array}$ \\
\hline 0 & $240 \pm 35.6$ & $++^{*}$ \\
\hline 0.1 & $258 \pm 5.5$ & $-*$ \\
\hline 0.2 & $264 \pm 14.0$ & $-*$ \\
\hline 0.5 & $244 \pm 9.0$ & $-{ }^{*}$ \\
\hline 1.0 & $259 \pm 20.8$ & $-*$ \\
\hline 1.5 & $251 \pm 14.6$ & $-*$ \\
\hline 2.0 & $244 \pm 31.8$ & $-*$ \\
\hline
\end{tabular}

The experiments were carried out in triplicate. The data are given as the number of colonies produced by $E$. coli in $0.5 \mathrm{ml}$ of the lactose-free counting medium. The symbols $\left(++^{*}\right)$ and $(-*)$ represent the presence and absence of cracks in the counting medium, respectively.

Table 4. Number of colonies produced by $E$. coli in the presence of B. bifidum using the selective medium for $E$. coli.

\begin{tabular}{cccc}
\hline \multicolumn{2}{c}{ Test strain } & & Number of colonies \\
\cline { 1 - 2 } $\begin{array}{c}E . \text { coli } \\
\text { (diln.) }\end{array}$ & $\begin{array}{c}\text { B. bifidum } \\
\text { (diln.) }\end{array}$ & $10^{0}$ & Mean \pm SD \\
\hline $10^{5}$ & $10^{1}$ & $214 \pm 20.5$ \\
$10^{5}$ & $10^{2}$ & $193 \pm 19.9$ \\
$10^{5}$ & $10^{3}$ & $173 \pm 6.7$ \\
$10^{5}$ & $10^{4}$ & $178 \pm 9.5$ \\
$10^{5}$ & $10^{5}$ & $184 \pm 20.7$ \\
$10^{5}$ & $10^{6}$ & $184 \pm 9.3$ \\
$10^{5}$ & $*$ & $188 \pm 4.2$ \\
$10^{5}$ & & $187 \pm 2.1$ \\
\hline
\end{tabular}

Both $0.1 \mathrm{ml}$ of $10^{5}$-fold diluted culture of $E$. coli and appropriately diluted B. bifidum were added to selective medium for $E$. coli. The experiments were carried out in triplicate. The data were shown as in Table 3. The symbol $(*)$ represents that saline was replaced with diluted culture of $B$. bifidum.

Interactions between both bacteria under the conditions in which they grew well in their pure culture

In order to grow well in their pure culture, they were incubated anaerobically at $37^{\circ} \mathrm{C}$ in Medium D. Figure 1 shows the growth and $\mathrm{pH}$ values in their pure culture. 


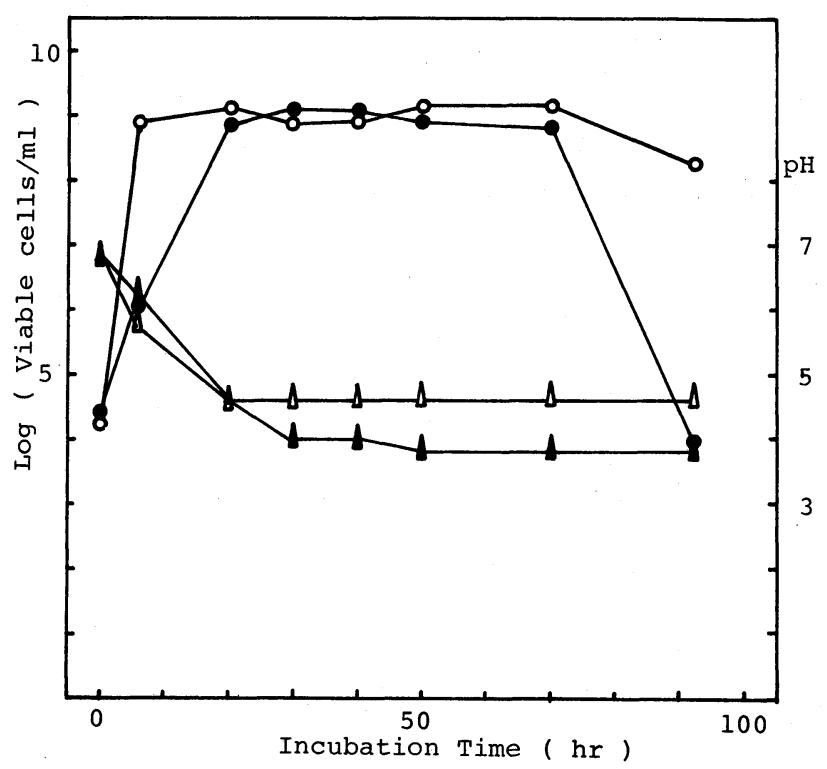

Fig. 1. Growth of B. bifidum and E. coli in an anaerobic pure culture and the $\mathrm{pH}$ values in their culture. An aliquot $(0.1 \mathrm{ml})$ of suspension containing $B$. bifidum or $E$. coli (about $10^{6}$ viable cells $/ \mathrm{ml}$ ) precultured according to the procedures described in this text, was inoculated into $6.9 \mathrm{ml}$ of Medium D and incubated anaerobically for $92 \mathrm{hr}$ at $37^{\circ} \mathrm{C}$. Symbols (--) and $\left(-\mathrm{O}^{-}\right)$represent the viable cells in $1 \mathrm{ml}$ of each culture of $B$. bifidum and E. coli, respectively. Triangles $\left(-\Delta_{-},-\Delta_{-}\right)$similarly represent the $\mathrm{pH}$ values of the culture.

The generation time of $E$. coli was shorter than that of $B$. bifidum, and the $\mathrm{pH}$ value of the culture of $B$. bifidum (3.8) became lower than that of $E$. coli (4.6). In their mixed culture under the same conditions (Fig. 2), the $\mathrm{pH}$ value of the culture approached 4.0 after $30 \mathrm{hr}$, when the growth of $E$. coli was depressed rapidly. Additionally, even when the number of viable celis of $E$. coli inoculated was $10^{4}$-fold that of $B$. bifidum, and when $B$. bifidum was inoculated into the culture in which $E$. coli had been incubated for $41 \mathrm{hr}$, the growth of $E$. coli was similarly inhibited (not shown in the Figure).

As described above, the inhibition of the growth of E. coli was closely associated with the $\mathrm{pH}$ values of the cultures. Therefore, we attempted to prevent the $\mathrm{pH}$ values of the cultures from lowering by the addition of an appropriate quantity of $2 \mathrm{~N} \mathrm{NaOH}$ just after samplings. As shown in Fig. 3, no inhibition was observed. On the contrary, as shown in Table 5, some acids had an inhibitory effect on the growth of $E$. coli even at the initial $\mathrm{pH}$ of 6.5 . Acetic acid and lactic acid, the metabolites of $B$. bifidum showed a relatively potent inhibition, and PABA, a bacterial vitamin, completely inhibited the growth of $E$. coli at a higher concentration $(60 \mathrm{~mm})$. 


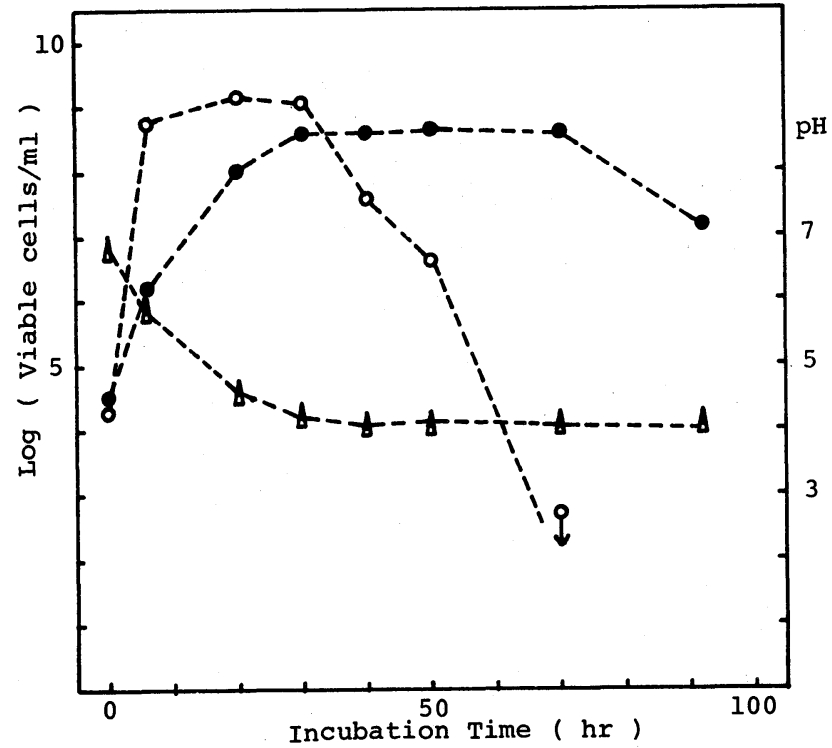

Fig. 2. Growth of B. bifidum and E. coli in their anaerobic mixed culture and the $\mathrm{pH}$ values in their culture. Aliquots $(0.1 \mathrm{ml})$ of bacterial suspension (about $10^{6}$ viable cells $/ \mathrm{ml}$ ) were inoculated into $6.8 \mathrm{ml}$ of Medium D. The following procedures were the same as in Fig. 1. Arrows ( $q$ ) indicate that the number of viable cells $/ \mathrm{ml}$ of the culture are under the indicated values. Viable

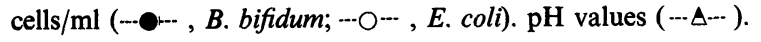

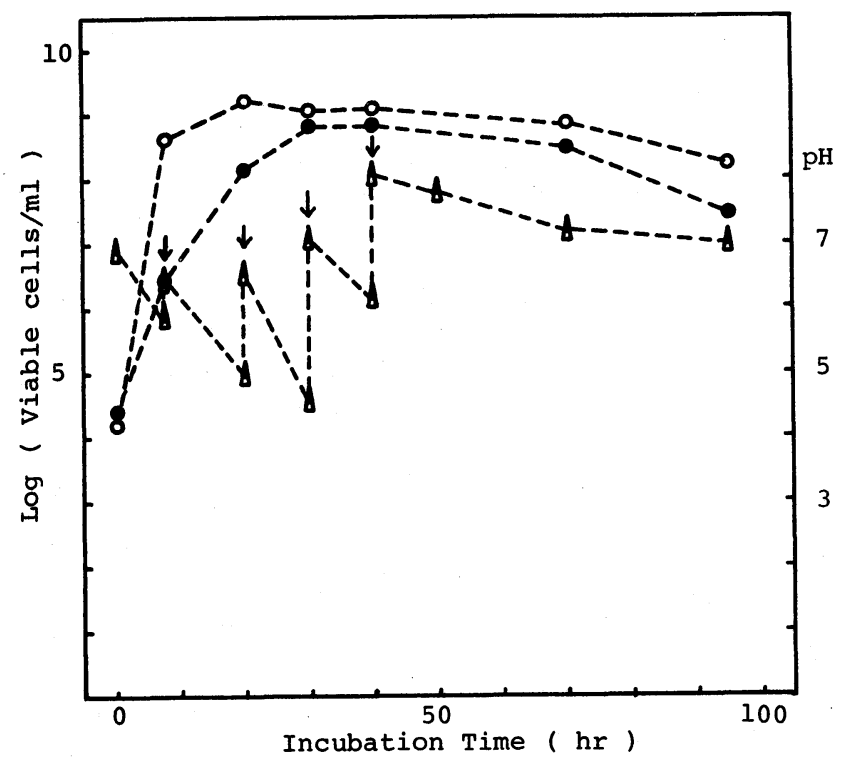

Fig. 3. Effect of prevention of $\mathrm{pH}$ values of the culture from lowering on the growth of both bacteria in the anaerobic mixed culture. Aliquots $(0.1 \mathrm{ml})$ of bacterial suspension (about $10^{6}$ viable cells $/ \mathrm{ml}$ ) were inoculated into $6.8 \mathrm{ml}$ of Medium $\mathrm{D}$ and incubated for $95 \mathrm{hr}$ at $37^{\circ} \mathrm{C}$. During incubation, an appropriate quantity of $2 \mathrm{~N} \mathrm{NaOH}$ was added to the culture to prevent $\mathrm{pH}$ values from lowering. Arrows represent the times when $\mathrm{NaOH}$ was added. Viable cells/ml

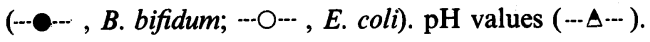


Interactions between both bacteria under conditions in which B. bifidum did not grow in the pure culture

B. bifidum required riboflavin and pantetheine in anaerobic incubation and did not grow in aerobic incubation even in complete GM-medium (Table 6). On the

Table 5. Effect of acids on the growth of E. coli.

\begin{tabular}{|c|c|c|c|c|c|}
\hline \multirow{2}{*}{ Acid } & \multirow{2}{*}{$\left(p K_{\mathrm{a}_{1}}\right)$} & \multicolumn{4}{|c|}{$\begin{array}{l}\text { Growth response } \mathrm{OD}_{650 \mathrm{~nm}} \\
\text { incubation time }(\mathrm{hr})\end{array}$} \\
\hline & & 10 & 20 & 35 & 51 \\
\hline Hydrochloric & - & 0.72 & 0.83 & 0.87 & 0.89 \\
\hline Tartaric & 2.93 & 0.05 & 0.58 & 1.05 & 1.12 \\
\hline Fumaric & 3.03 & 0.11 & 1.06 & 1.29 & 1.32 \\
\hline Citric & 3.09 & 0.62 & 1.42 & 1.47 & 1.54 \\
\hline Formic & 3.75 & 0.08 & 0.91 & 1.00 & 1.13 \\
\hline Lactic & 3.87 & 0.35 & 0.46 & 0.47 & 0.54 \\
\hline Succinic & 4.21 & 0.24 & 0.63 & 0.70 & 0.71 \\
\hline p-Aminobenzoic & 4.65 & 0.01 & 0.01 & 0.02 & 0.03 \\
\hline Acetic & 4.76 & 0.02 & 0.36 & 0.55 & 0.61 \\
\hline Butyric & 4.82 & 0.02 & 0.25 & 0.61 & 0.63 \\
\hline Propionic & 4.87 & 0.01 & 0.16 & 0.60 & 0.63 \\
\hline
\end{tabular}

An aliquot $(0.1 \mathrm{ml})$ of the suspension of $E$. coli $\left(10^{6}\right.$ viable cells $\left./ \mathrm{ml}\right)$ was inoculated into the $7 \mathrm{ml}$ of Medium D ( $\mathrm{pH} \mathrm{6.5)} \mathrm{containing} 60 \mathrm{~mm}$ of test compound and incubated anaerobically for $51 \mathrm{hr}$ at $37^{\circ} \mathrm{C}$. The $\mathrm{OD}$ values at $650 \mathrm{~nm}$ were corrected for those of the blank.

Table 6. Requirement of vitamins for the growth of B. bifidum and E. coli and effect of anaerobic condition on it.

\begin{tabular}{lcccc}
\hline & \multicolumn{3}{c}{ Growth response OD $_{650 \mathrm{~nm}}$} \\
\cline { 2 - 5 } & \multicolumn{2}{c}{ B. bifidum } & \multicolumn{2}{c}{ E. coli } \\
\cline { 2 - 5 } & Aerobic & Anaerobic & Aerobic & Anaerobic \\
\cline { 2 - 5 } & & & 0.45 & 0.36 \\
Complete & 0.02 & 1.10 & 0.47 & 0.27 \\
(-) Thiamine & 0.02 & 0.94 & 0.56 & 0.32 \\
(-) Riboflavin & 0.04 & 0.13 & 0.53 & 0.30 \\
(-) Nyridoxine & 0.03 & 0.89 & 0.55 & 0.34 \\
(-) PABA & 0.03 & 0.69 & 0.48 & 0.29 \\
(-) Folic acid & 0.04 & 0.79 & 0.57 & 0.36 \\
(-) Biotin & 0.05 & 0.57 & 0.50 & 0.38 \\
(-) Pantetheine & 0.02 & 0.57 & 0.50 & 0.20 \\
\hline
\end{tabular}

An aliquot $(0.1 \mathrm{ml})$ of the suspension of $B$. bifidum or $E$. coli $\left(10^{6}\right.$ viable cells $\left./ \mathrm{ml}\right)$ was inoculated into $7 \mathrm{ml}$ of a vitamin deficient GM-medium and incubated aerobically or anaerobically for $100 \mathrm{hr}$ at $37^{\circ} \mathrm{C}$. The OD values at $650 \mathrm{~nm}$ were corrected for those of blank. 
other hand, E. coli grew aerobically better than anaerobically and had no requirement for vitamins. We then investigated whether $B$. bifidum could grow or not in a mixed culture with $E$. coli under conditions in which the former did not grow in the pure culture. The growth of $B$. bifidum in riboflavin-deficient medium was enhanced significantly in the presence of $E$. coli, while such an enhancement disappeared after the decrease of viable cells of E. coli (Fig. 4). On the other hand, the growth of $B$. bifidum in the pantetheine-deficient medium was slightly stimulated by $E$. coli and a decrease of $E$. coli was not observed (Fig. 5).

B. bifidum did not survive aerobically in the pure culture but grew fully in the presence of $E$. coli. On the other hand, the growth of $E$. coli was inhibited completely after the $\mathrm{pH}$ value of the culture reached 4.6 (Fig. 6).

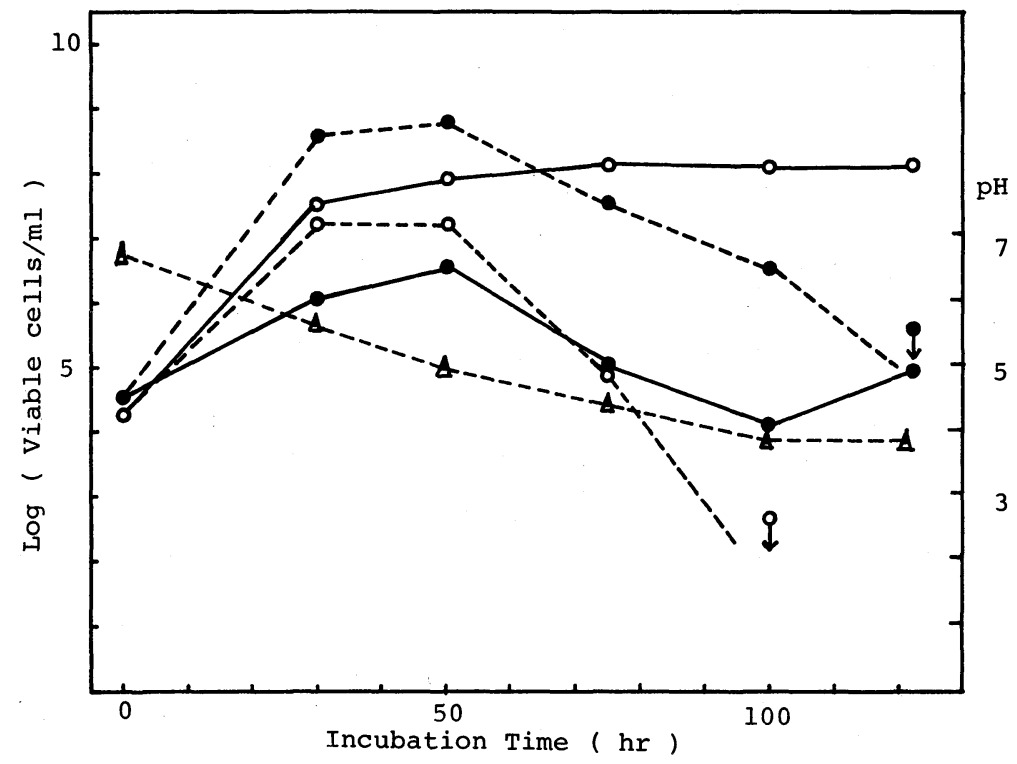

Fig. 4. Growth of bacteria under anaerobic incubation with riboflavin-deficient GM-medium. Aliquots $(0.1 \mathrm{ml})$ of bacterial suspension (about $10^{6}$ viable cells $/ \mathrm{ml}$ ) were inoculated into $6.8 \mathrm{ml}$ of GM-medium and incubated for $120 \mathrm{hr}$ at $37^{\circ} \mathrm{C}$. Viable cells $/ \mathrm{ml}$ in pure culture $(-\bullet-, B$. bifidum; - - - E. coli) and in mixed culture (----, B. bifidum; -,-- E. coli $)$. pH values in mixed culture $(\cdots \Delta-\cdots)$. 


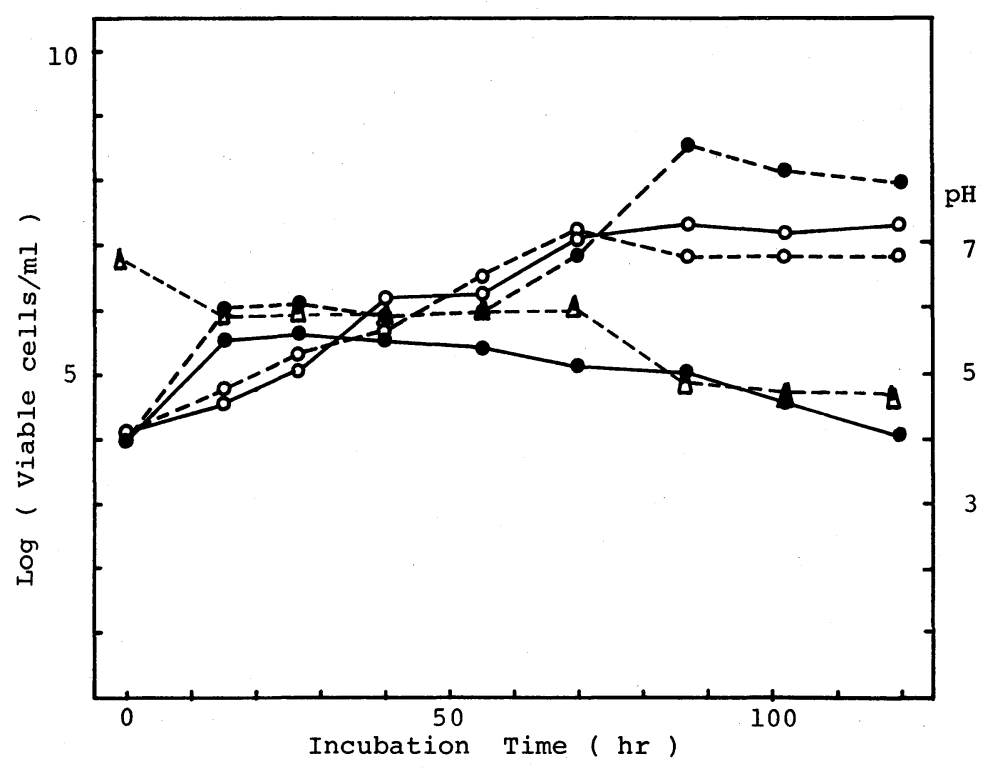

Fig. 5. Growth of bacteria under anaerobic incubation with pantetheine-deficient GM-medium. The procedures were the same in Fig. 4 . Viable cells $/ \mathrm{ml}$ in pure culture $(-\bullet-, B$. bifidum;

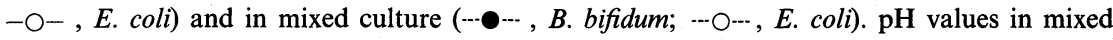
culture (--A- $-\cdots)$.

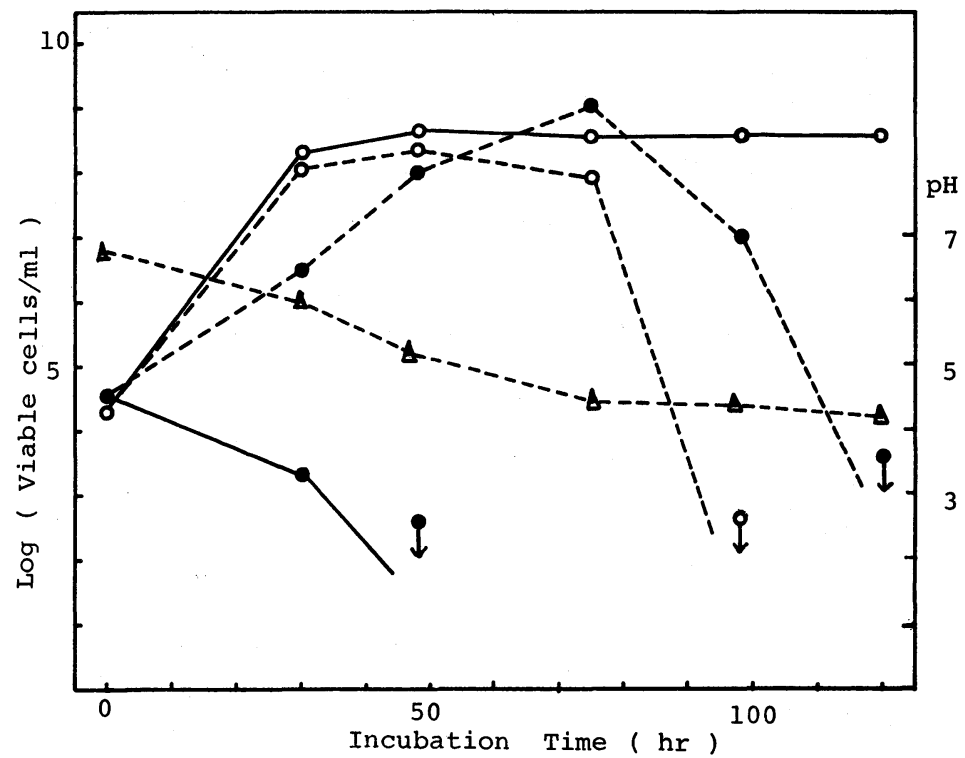

Fig. 6. Growth of bacteria under aerobic incubation with pyridoxine-deficient GM-medium. The procedures were the same as in Fig. 4. Viable cells/ml in pure culture $(-\bullet-$, B. bifidum;-O-, E.

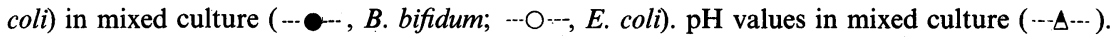




\section{DISCUSSION}

NAKAMURA et al. (7) developed a capillary tube method for counting B. bifidum viable cells by the use of a modified Medium $D$. This medium became selective for the bacteria by the addition of sodium azide and was not influenced by the presence of $E$. coli in our experiments (Tables 1 and 2). On the contrary, by the addition of potassium nitrate and the subtraction of lactose, the medium became suitable for counting of viable cells of $E$. coli (Tables 3 and 4).

B. bifidum is anaerobic and has a high requirement for nutrients. On the other hand, $E$. coli is aerobic and has a low requirement for nutrients. In their mixed culture, parasitism was remarkable under the conditions where B. bifidum was not able to grow by itself. Firstly, anaerobic condition, in which oxygen molecules toxic for the growth of $B$. bifidum exist, was changed to anaerobic by the better growth of $E$. coli. Secondly riboflavin and pantetheine, essential vitamins for the growth of $B$. bifidum, were probably provided in the medium by $E$. coli, though the supply of pantetheine is insufficient. It seems to be due to the contamination with biotin in vitamin-free casamino acids that $B$. bifidum did not require the vitamin for the growth.

B. bifidum is acid-producing while $E$. coli is not resistant to acids. When the former grew well in the mixed culture, the growth of $E$. coli was inhibited markedly probably because of the lowering of the $\mathrm{pH}$ values of the medium (Figs. 2, 3, 4, 5 and 6). The additional toxic effect of acetic and lactic acids by themselves (Table 5) would not be negligible though the mechanism is not clear.

There is a possibility that parasitism and antagonism between Bifidobacteria and E. coli similar to those observed in vitro might be present in the intestine in the formation of intestinal flora.

We express our gratitude to Dr. Yusaku Tagashira of Biochemistry Division, Saitama Cancer Center Research Institute for his encouragement in the preparation of this paper.

\section{REFERENCES}

1) Mitsuoka, T., and Kaneuchi, C. (1977): Ecology of the Bifidobacteria. Am. J. Clin. Nutr., 30, 1799-1810.

2) Stenger, K., and Wolf, H. (1962): Die Bedeutung des Bacterium bifidum für den Säuglingorganisms. Arch. Kinderheilkd., 46, 1-21.

3) Sandie, W. E., Muralidhara, K. S., Elliker, P. R., and England, D. C. (1972): Lactic acid bacteria in food and health: A review with special reference to enteropathogenic Escherichia coli as well as certain enteric diseases and their treatment with antibiotics and Lactobacilli. J. Milk Food Technol., 35, 691-702.

4) ToRrey, J. C., and KAHN, M. C. (1923): The inhibition of putrefactive spore-bearing anaerobes by Bacterium acidophilus. J. Infect. Dis., 33, 482-497.

5) Young, G., KRASNer, R. I., and YUdKOFSKy, P. L. (1956): Interactions of oral strains of Candida albicans and Lactobacilli. J. Bacteriol., 72, 525-529.

6). Yanagita, T. (1956): Capillary tube method for counting viable bacteria. J. Bacteriol., 71, 381-382. 
7) Nakamura, H., Samejima, K., and Tamura, Z. (1974): A capillary tube method for counting viable cells of Bifidobacterium bifidum grown in a solid medium. Jpn. J. Microbiol., 18, 135-138.

8) Yoshioka, M., Yoshioka, S., TAmura, Z., and Oнta, K. (1968): Growth responses of Bifidobacterium bifidum to coenzyme A, its precursors and carrot extract. Jpn. J. Microbiol., 12, 395-402.

9) Nakamura, H., Samejima, K., Saito, Y., and Tamura, Z. (1971): A new ultra-micro microbioassay. Chem. Pharm. Bull., 19, 436-438.

10) Nakamura, H., Samejima, K., and Tamura, Z. (1974): Growth of Bifidobacterium bifidum N4 in solid medium limited by exogenous lactose. Jpn. J. Microbiol., 18, 185-186. 